\title{
ДІАГНОСТИЧНІ КРИТЕРІЇ НЕВРАСТЕНІї З ПІДВИЩЕНИМ РИЗИКОМ АДДИКТИВНОї ПОВЕДІНКИ
}

\author{
ДУ «Інститут неврології, психіатрії та наркології НАМН України», м. Харків, Україна
}

\begin{abstract}
Мета: визначити клінічні особливості та закономірності фрормування неврастенії з підвищеним ризиком аддиктивної поведінки.

Матеріали і методи. У дослідженні взяли участь 46 хворих на неврастенію (F 48.0), серед яких за даними AUDIT-подібних тестів виявили 26 пацієнтів з аддикціями (основна група) та 20 - без аддикцій (контрольна група).

Результати. За результатами проведеного дослідження пацієнтів із неврастенією, поєднаною з аддиктивними порушеннями, виявлено, що затяжний тип фрормування невротичного розладу, наявність емоційноізоляційних психотравмуючих чинників, широкий спектр клініко-психопатологічних симптомів із домінуванням соматовегетативних та депресивних проявів, входять до синдромальної структури провідного астенічного синдрому на тлі соматовегетативного, дисороричного або депресивного синдромів. Одним із найбільш інорормативних маркерів наявності аддикцій у хворих на неврастенію $€$ наявність затяжного початку хвороби $(\mathrm{Ml}=0,83)$ та диссоричного синдрому $(\mathrm{Ml}=0,8)$.

Причиною невротичних розладів з аддикціями було переважно поєднання гострих та хронічних психотравмуючих чинників із різних сорер життєдіяльності людини; окрім цього значна частка в формуванні неврозів 3 аддикціями належала емоційно-ізоляційним психотравмуючим чинникам, що пов'язані з переживанням відчуття самотності та відчуженості.
\end{abstract}

Висновок. Отримані дані можуть бути використані для удосконалення програм діагностики, профрілактики та терапії хворих на неврастенію.

КЛЮЧОВІ СЛОВА: неврастенія; аддикція; коморбідність; клініко-психопатологічні ознаки; діагностичні критерії.

У загальній структурі психічних захворювань переважна частка належить непсихотичним психічним розладам, що пов'язані насамперед зі стресовими, психотравмуючими чинниками, зниженням адаптаційних ресурсів особистості в сучасних умовах геополітичних змін, загроз терористичних актів, військових конфрліктів та загалом стрімким темпом життя та інформаційного прогресу [1-4]. За цих умов у структурі клінічних проявів сучасних невротичних розладів все частіше спостерігали наявність аддиктивних порушень $[5,6]$. Одним із найпоширеніших варіантів коморбідності $€$ поєднання невротичної хвороби з аддиктивними розладами. Так, стани залежності від різних об'єктів вживання фріксували у 61,82 \% хворих на дисоціативні розлади, у 56,52 \% хворих на тривожно-фробічні розлади та у 56,52 \% хворих на неврастенію [9]. Проте дані відносно особливостей перебігу, формування та перебігу невротичних розладів із коморбідними аддикціями в літературі відсутні, що становить певні труднощі в діагностиці та терапії подібних станів та зумовлює актуальність та доцільність запропонованої роботи.

Мета дослідження: визначити клінічні особливості та закономірності формування неврастенії 3 підвищеним ризиком аддиктивної поведінки.

(с) М.М. Денисенко, 2017
Матеріали і методи. У дослідженні взяли участь 46 хворих на неврастенію ( $F$ 48.0), серед яких за даними AUDIT-подібних тестів виявили 26 пацієнтів 3 аддикціями (основна група) та 20 без аддикцій (контрольна група).

Серед методів дослідження використовували клініко-психопатологічний метод; систему AUDITподібних тестів; клінічний опитувальник для виявлення та оцінки невротичних станів; а також клініко-статистичні методи аналізу отриманих даних із використанням комп'ютерних програм Excel та SPSS.

Клініко-психопатологічний метод включав збір анамнестичних даних, проведення клінічного інтерв'ю, спостереження за хворими та доповнювався використанням клінічних оціночних методик: системи AUDIT-подібних тестів для комплексної оцінки аддиктивного статусу та клінічного опитувальника для виявлення та оцінки невротичних станів $[7,8]$.

Результати дослідження та їх обговорення. Результати аналізу особливостей фоомування та перебігу неврастенії у хворих наведено в таблиці 1.

Згідно з отриманими даними, у обстежених хворих на неврастенію з аддиктивними порушеннями початок невротичного розладу також був переважно підгострим (53,85 \%) або затяжним (38,48 \%). При цьому саме затяжний тип фрормування 
Таблиця 1. Особливості формування та перебігу неврастенії у хворих досліджуваних груп

\begin{tabular}{|c|c|c|c|c|c|}
\hline \multirow{3}{*}{ Критерій } & \multicolumn{5}{|c|}{ Неврастенія (F 48.0) } \\
\hline & \multicolumn{2}{|c|}{$\begin{array}{c}\text { основна група } \\
\text { n=26 }\end{array}$} & \multicolumn{2}{|c|}{$\begin{array}{c}\text { контрольна група } \\
\text { n=20 }\end{array}$} & \multirow{2}{*}{$p$} \\
\hline & абс. & $\%$ & абс. & $\%$ & \\
\hline \multicolumn{6}{|c|}{ Початок хвороби } \\
\hline Гострий & 2 & 7,69 & 2 & 10 & 0,3784 \\
\hline Підгострий & 14 & 53,85 & 16 & 80 & 0,0472 \\
\hline Затяжний & 10 & 38,46 & 2 & 10 & 0,0259 \\
\hline \multicolumn{6}{|c|}{ Перебіг хвороби } \\
\hline Періодичний & 3 & 11,54 & 4 & 20 & 0,1545 \\
\hline Нападоподібний & 12 & 46,15 & 9 & 45 & 0,2337 \\
\hline Безперервний & 11 & 42,3 & 7 & 35 & 0,2125 \\
\hline \multicolumn{6}{|c|}{ Тривалість хвороби } \\
\hline До 1 року & 5 & 19,23 & 7 & 35 & 0,1311 \\
\hline До 3 років & 12 & 46,15 & 9 & 45 & 0,2336 \\
\hline Понад 3 роки & 9 & 34,61 & 4 & 20 & 0,1488 \\
\hline
\end{tabular}

Примітка. Достовірність відмінностей між групами на рівні: $p<0,05 ; p<0,01$ виділено заливкою сірого кольору різної інтенсивності.

невротичного розладу спостерігали достовірно частіше серед хворих на неврастенію $з$ аддикціями (38,48 \%), ніж у хворих без аддикцій (10\%), при $\mathrm{p}=0,0259$. Тоді як у хворих без аддикцій фрормування неврастенії здебільшого відбувалось підгостро (в $80 \%$ випадків), порівняно 3 хворими 3 аддикціями (53,85\%), при р=0,0472.

Переважання нападоподібного типу перебігу свідчило про наявність у більшості хворих на неврастенію, незалежно від фрорми та групи порівняння, так званої невротичної готовності, коли майже незначний чинник призводив до запуску невротичної симптоматики.

Аналіз психогенних чинників у хворих груп обстеження наведено в таблиці 2.

Згідно з даними, у хворих на неврастенію обох груп найчастіше фріксували психотравми в сімейно-особистісній (у 38,46 \% хворих із аддикціями та у $60 \%$ хворих без аддикцій) та професійній сорерах (у 34,62 \% хворих з аддикціями та в 50 \% хворих без аддикцій). Відмінності між групами порівняння при неврастенії спостерігали в значному переважанні емоційно-ізоляційних чинників, що були пов'язані з відчуттям самотності, у хворих 3 аддикціями (19,23 \%), тоді як у хворих без аддикцій наявність подібних психотравм не була зафріксована $(p=0,048)$.

Особливості та виразність невротичної симптоматики у обстежених осіб оцінювали за допомогою клінічного опитувальника для виявлення та оцінки рівня невротизації К. К. Яхіна та Д. М. Менделевича. Отримані дані в порівняльному аспекті двох груп (основної - 3 аддиктивними порушеннями в клінічній картині; та контрольної - без аддикцій) наведено в таблиці 3. Варто зазначити, що діагностичні коефріцієнти оцінки рівня невротизації за даним опитувальником мають зворотне значення та $€$ показниками самооцінки свого стану безпосередньо хворими: чим нижчий показник, тим вищий рівень невротизації, і - навпаки. Критичним рівнем, що свідчить про наявність хворобливих проявів за розладами, які оцінюються, $€$ показник «-1,28».

Згідно з отриманими даними, у хворих на неврастенію (F 48.0) з аддикціями в клінічній картині відзначали більшу інтенсивність психопатологічних проявів, зокрема соматовегетативних порушень $(-4,63 \pm 1,11$, при $p=0,0212)$, депресивних проявів $(-4,75 \pm 0,74)$, істеричного типу реагування $(-2,15 \pm 0,78)$, обсесивно-фробічних порушень $(-2,11 \pm 0,81)$, астенії $(-2,04 \pm 0,63)$ та тривоги $(-1,85 \pm 0,86)$. Хворі на неврастенію без аддикцій відзначали на рівні хворобливого стану наявність лише симптомів невротичної депресії $(-2,58 \pm 1,01)$.

Отримані дані доповнювались оцінкою провідних клініко-психопатологічних синдромів у групах обстежених осіб. Синдромальна структура неврастенії ( $F$ 48.0) за групами порівняння показана на рисунку 1.

Як показано на рисунку 1 , у хворих на неврастенію (F 48.0) в поєднанні з аддикціями в синдромальній структурі значно частіше спостерігали наявність складних синдромокомплексів, де провідний астенічний синдром поєднувався переважно $з$ соматовегетативним (53,84 \%), депресивним 
Таблиця 2. Провідні чинники психічної травматизації, що призвели до розвитку невротичного захворювання

\begin{tabular}{|c|c|c|c|c|c|}
\hline \multirow{3}{*}{ Чинники психічної травматизації } & \multicolumn{5}{|c|}{ Неврастенія (F 48.0) } \\
\hline & \multicolumn{2}{|c|}{$\begin{array}{l}\text { основна група } \\
(\mathrm{n}=26)\end{array}$} & \multicolumn{2}{|c|}{$\begin{array}{l}\text { контрольна група } \\
(\mathrm{n}=20)\end{array}$} & \multirow[t]{2}{*}{$\mathrm{p}$} \\
\hline & абс. & $\%$ & абс. & $\%$ & \\
\hline \multicolumn{6}{|l|}{ За тривалістю дії } \\
\hline Гострі & 5 & 19,23 & 5 & 25 & 0,2502 \\
\hline Хронічні & 12 & 46,15 & 10 & 50 & 0,2261 \\
\hline Поєднані & 9 & 34,62 & 5 & 25 & 0,2019 \\
\hline \multicolumn{6}{|l|}{ За сорерами життєдіяльності } \\
\hline $\begin{array}{l}\text { Пов'язані з професійною діяльністю (втрата роботи, службо- } \\
\text { ві конорлікти, напруження/навантаження на роботі тощо) }\end{array}$ & 9 & 34,62 & 10 & 50 & 0,1389 \\
\hline $\begin{array}{l}\text { Матеріально-побутові (погіршення матеріально-побутового } \\
\text { рівня життя, зміна місця проживання тощо) }\end{array}$ & 5 & 19,23 & 2 & 10 & 0,2335 \\
\hline $\begin{array}{l}\text { Пов'язані зі здоров'ям (власна хвороба, хвороба близької } \\
\text { людини, ятрогенії) }\end{array}$ & 6 & 23,08 & 4 & 20 & 0,2736 \\
\hline $\begin{array}{l}\text { Сімейно-особистісні (розпад сім'ї, сімейно-побутові конфр- } \\
\text { лікти, відсутність емоційної підтримки, ревнощі, зрада) }\end{array}$ & 10 & 38,46 & 12 & 60 & 0,0848 \\
\hline Емоційно-ізоляційні (пов'язані з відчуттям самотності) & 5 & 19,23 & - & - & 0,048 \\
\hline $\begin{array}{l}\text { Стресові потрясіння (дорожньо-транспортні пригоди, не- } \\
\text { щасні випадки, арешти, злочинні дії тощо) }\end{array}$ & - & - & - & - & - \\
\hline
\end{tabular}

Примітка. Достовірність відмінностей між групами на рівні: $p<0,05 ; p<0,01$ виділено заливкою сірого кольору різної інтенсивності.

Таблиця 3. Виразність невротичної симптоматики у осіб із неврастенією (результати обстеження за допомогою опитувальника Яхіна-Менделевича)

\begin{tabular}{|l|c|c|c|}
\hline \multirow{2}{*}{\multicolumn{1}{c|}{ шкала }} & \multicolumn{3}{c|}{ Неврастенія (F 48.0) } \\
\cline { 2 - 4 } & $\begin{array}{c}\text { основна група } \\
(\mathrm{n}=26)\end{array}$ & $\begin{array}{c}\text { контрольна група } \\
(\mathrm{n}=20)\end{array}$ & 0,2201 \\
\hline Тривога & $-1,85 \pm 0,86$ & $-0,29 \pm 0,91$ & 0,0857 \\
\hline Невротична депресія & $-4,75 \pm 0,74$ & $-2,58 \pm 1,01$ & 0,1359 \\
\hline Астенія & $-2,04 \pm 0,63$ & $-0,20 \pm 1,09$ & 0,3321 \\
\hline Істеричний тип реагування & $-2,15 \pm 0,78$ & $-0,86 \pm 1,09$ & 0,2632 \\
\hline Обсесивно-сробічні порушення & $-2,11 \pm 0,81$ & $-0,84 \pm 0,75$ & 0,0212 \\
\hline Вегетативні порушення & $-4,63 \pm 1,11$ & $-0,51 \pm 1,33$ & 0,6329 \\
\hline Алекситимія & $255,92 \pm 3,57$ & $253,5 \pm 3,38$ & \\
\hline
\end{tabular}

Примітки: значення подано у фрорматі «Середня арифметична \pm стандартна похибка середньої арифметичної» $(\mathrm{M} \pm \mathrm{m})$; достовірність відмінностей між групами на рівні: $p<0,05 ; p<0,01$ виділено заливкою сірого кольору різної інтенсивності.

(46,15\%), тривожним (42,3\%) та дисороричним (26,92 \%) синдромами. Саме депресивний, соматовегетативний та дисороричний синдроми значно частіше були наявні в структурі неврастенії у хворих 3 аддикціями, порівняно 3 контрольною групою, при p=0,0472; $p=0,05 ; p=0,05$, відповідно.

У хворих на неврастенію без аддикцій синдромальна структура була менш різноманітною, провідний астенічний синдром лише в $30 \%$ випадків поєднувався з тривожним, у 25 \% випадків - 3 соматовегетативним та в $20 \%$ - 3 депресивним, інші синдроми були наведені ще в меншій відсотковій частці.
3 метою використання клінічних особливостей невротичних розладів як додаткових діагностичних ознак-маркерів наявності або відсутності аддикцій в структурі неврастенії було проведено частотний аналіз за групами порівняння та розраховано їх діагностичні коефріцієнти (ДК) та міри інформативності Кульбака (MI) 3 наступним використанням послідовного статистичного аналізу (процедура Вальда в модифікації Гублера). У таблиці 4 наведено лише статистично значущі ознаки, частоти представленості яких в групах порівняння достовірно відрізнялись $(p \leq 0,05)$. 


\section{Неврастенія (F 48.0)}

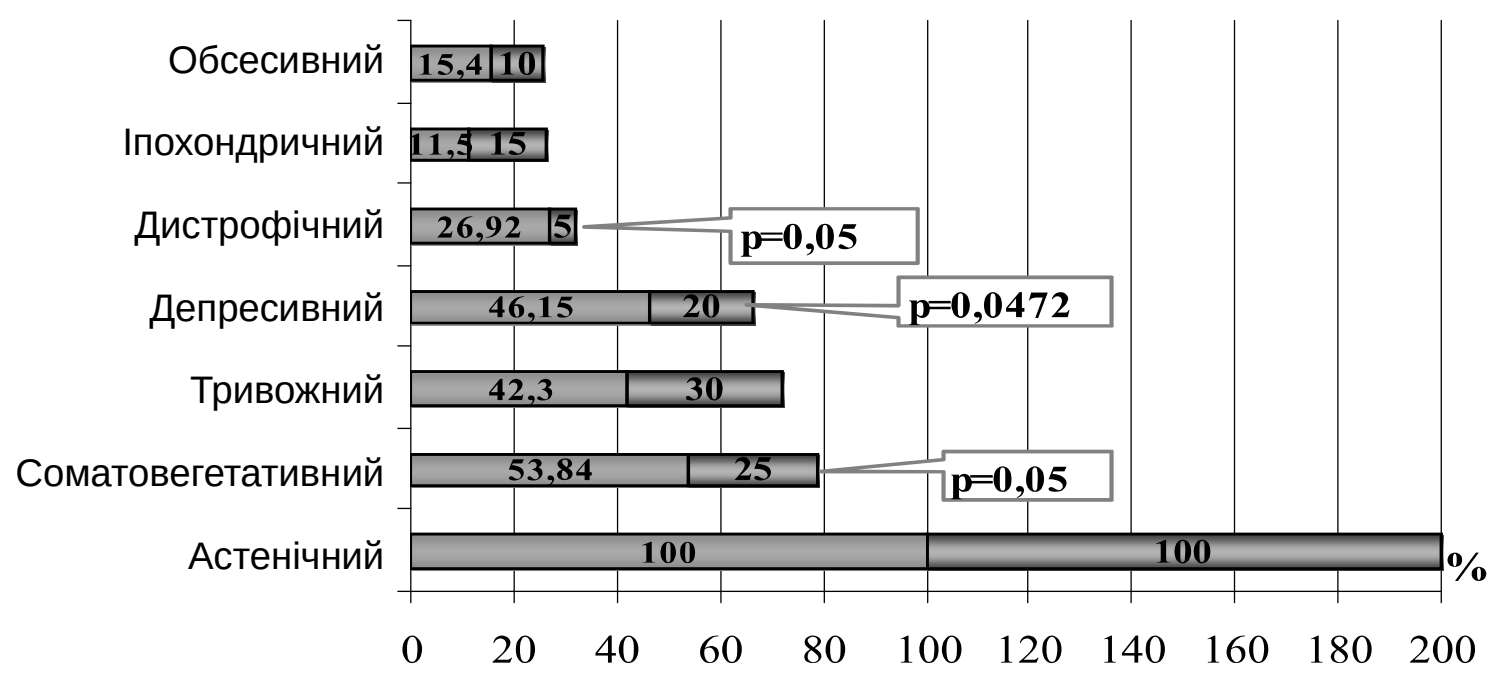

F 48.0 заддикціями (n=26) 口 F 48.0 без аддикцій $(\mathrm{n}=20)$

PUC. 1. Синдромальна структура неврастенії (F 48.0) за групами порівняння.

Таблиця 4. Прогностичні клініко-психопатологічні ознаки наявності або відсутності аддиктивних порушень при неврастенії (F 48.0)

\begin{tabular}{|c|c|c|c|c|}
\hline Прогностичні ознаки & $\begin{array}{l}\text { Градація } \\
\text { ознаки }\end{array}$ & $\mathrm{p}^{1}$ & $Д \mathrm{~K}^{2}$ & $\mathrm{Ml}^{3}$ \\
\hline \multicolumn{5}{|c|}{ Ознаки наявності аддикцій } \\
\hline Затяжний початок хвороби & + & 0,0259 & 5,85 & 0,83 \\
\hline Дисороричний синдром & + & 0,05 & 7,31 & 0,8 \\
\hline Соматовегетативний синдром & + & 0,0360 & 3,33 & 0,48 \\
\hline Депресивний синдром & + & 0,0472 & 3,63 & 0,47 \\
\hline \multicolumn{2}{|c|}{$\begin{array}{l}\text { Загальний рівень диференціації та інфрормативності (за сукупністю } \\
\text { ознак - } \text { СКК і } \sum \text { МІ) }\end{array}$} & $<0,01$ & 20,12 & 2,58 \\
\hline \multicolumn{5}{|c|}{ Ознаки відсутності аддикцій } \\
\hline $\begin{array}{l}\text { Рівень вегетативних порушень нижчий за середньогру- } \\
\text { повий }\end{array}$ & $\geq-2,71 \pm 0,90^{4}$ & 0,0307 & $-2,74$ & 0,42 \\
\hline Рівень астенії нижчий за середньогруповий & $\geq-1,19 \pm 0,62^{4}$ & 0,05 & $-2,28$ & 0,30 \\
\hline Підгострий початок хвороби & & 0,0472 & $-1,72$ & 0,22 \\
\hline \multicolumn{2}{|c|}{$\begin{array}{l}\text { Загальний рівень дифреренціації та інфрормативності (за сукупністю } \\
\text { ознак - } 2 \text { ДК і } \sum \text { МІ) }\end{array}$} & $>0,05$ & $-6,74$ & 0,94 \\
\hline
\end{tabular}

Примітки: ${ }^{1}$ - вірогідність відмінностей; ${ }^{2}-$ діагностичний коефіцієнт; ${ }^{3}-$ міра інфрормативності; ${ }^{4}-$ показник $3 а$ методикою оцінки невротичних станів К. К. Яхіна та Д. М. Менделевича.

За результатами процедури послідовного статистичного аналізу достовірний рівень диореренціації $(p \leq 0,05)$ наявності або відсутності аддикцій в структурі неврастенії можливий за умови досягнення критичного значення діагностичного коефіцієнта (ДК $\geq 13$ ) однією з ознак або їх сукупністю. При цьому ДК виділених ознак сумують, доки не буде досягнуто достовірного рівня диференціації: ДК>13, 20 або 30 для $p \leq 0,05, p \leq 0,01$ та $p \leq 0,001$, відповідно.
Знак ДК (+ або -) залежить від співвідношення осіб, які $€$ носіями відповідних ознак у групах порівняння, та від порядку розташування (нумерації) груп. У нашому випадку група хворих без аддикцій була першою, а група хворих на невротичні розлади 3 аддикціями - другою. У такому випадку, маркери наявності аддикцій в структурі неврастенії мають позитивне значення ДК (+), а маркери відсутності аддикцій - негативне значення ДК (-). 
Варто зауважити, що відповідно до отриманих в дослідженні даних, у хворих на неврастенію жодна з виділених нижче ознак не сягає критичного рівня, тому не $є$ самодостатньою, а може розглядатись як діагностичний маркер наявності або відсутності аддикцій лише в сукупності з іншими ознаками.

Достовірний висновок про наявність станів залежностей у хворих на неврастенію можливий при наявності двох перших ознак: наявності затяжного початку хвороби (ДК=5,85) та дисороричного синдрому (ДК=7,31), які в поєднанні забезпечують достовірність диференціації на рівні р<0,05 (сукупне ДК=13,16).

Необхідно зазначити, що ознаки наявності аддикцій у хворих на неврастенію виявилися більш інформативними порівняно 3 ознаками їх відсутності. Показник співвідношення загального рівня інфрормативності за сукупністю виділених ознак склав 2,74 ( $\sum \mathrm{MI}$ ознак наявності аддикцій $(2,58) / \sum \mathrm{Ml}$ ознак відсутності аддикцій $\left.(0,94)=2,74\right)$. Загалом діагностика наявності аддикцій у хворих на неврастенію за виділеними ознаками можлива (достовірність може сягати рівня $р<0,01$ ), тоді як висновок про їх відсутність за виділеними ознаками не буде достовірним, тому що сукупний рівень їх ДК не сягає 13 балів.

Таким чином, за результатами проведеного дослідження пацієнтів із неврастенією, поєднаною 3 аддиктивними порушеннями, виявлено, що затяжний тип фрормування невротичного розладу, наявність емоційно-ізоляційних психотравмуючих чинників, широкий спектр клінікопсихопатологічних симптомів, із домінуванням соматовегетативних та депресивних проявів, входять до синдромальної структури провідного астенічного синдрому на тлі соматовегетативного, дисфроричного або депресивного синдромів. Одним із найбільш інформативних маркерів наявності аддикцій у хворих на неврастенію $€$ наявність затяжного початку хвороби $(\mathrm{Ml}=0,83)$ та дисороричного синдрому $(\mathrm{Ml}=0,8)$.

Причиною невротичних розладів із аддикціями були переважно поєднані варіанти психотравм, тобто поєднання гострих та хронічних психотравмуючих чинників (особливо при тривожнофробічних та дисоціативних розладах) із різних сорер життєдіяльності людини; окрім цього значна частка в фрормуванні неврозів 3 аддикціями належала емоційно-ізоляційним психотравмуючим чинникам, що пов'язані $з$ переживанням відчуття самотності та відчуженості (особливо при неврастенії).

Висновок. Отримані дані можуть бути використані для удосконалення програм діагностики, профрілактики та терапії хворих на неврастенію.

Перспективи подальших досліджень полягають у подальшому вивченні фракторів ризику розвитку невротичних розладів.

\section{Список літератури}

1. Стан психічного здоров'я населення та перспективи розвитку психіатричної допомоги в Україні [Текст] / М. К. Хобзей, П. В. Волошин, Н. О. Марута [та ін.] / Український вісник психоневрології. - 2012. - Т. 20, вип. 3 (72). C. 13-19.

2. Волошин П. В. Стратегия охраны психического здоровья населения Украины: современные возможности и препятствия / П. В. Волошин, Н. А. Марута // Український вісник психоневрології. - 2015. - Т. 23, вип. 1 (82). C. 5-11.

3. Чабан О. С. Патоморфоз неврозов (клинико-психопатологические, социально-психологические и конституционально-биологические закономерности) [Текст] : дис. ... доктора мед. наук : 14.01.16 / О. С. Чабан. - Х., 1997. - 455 c.

4. Зільберблат Г. М. Реформування психіатричної служби крізь призму наркологічних проблем / Г. М. Зільберблат // Український вісник психоневрології. - 2015. - Т. 23, вип. 3 (84). - С. 74-78.

5. Битенский В. С. Клинико-психопатологические аспекты трансформации аддиктивного поведения в условиях «Инорормационного взрыва» [Текст] / В. С. Битенский, К. В. Аймедов, В. А. Пахмурный // Вісник психіатрії та психофрармакотерапії. - 2006. - № 1. - С. 161-167.

6. Клинико-психопатологические особенности тревожно-фробических расстройств с аддиктивными нарушениями [Текст] / Н. А. Марута, С. П. Колядко, М. М. Денисенко, Г. Ю. Каленская // Український вісник психоневрології. 2015. - T. 23, № 2 (83). - С. 115-116.

7. Менделевич В. Д. Психология девиантного поведения : учебное пособие / В. Д. Менделевич. - СПб. : Речь, 2005. - 445 c.

8. Система AUDIT-подобных тестов для комплексной оценки аддиктивного статуса индивида и популяции / И. В. Линский, А. И. Минко, А. Ф. Артемчук [и др.] // Новости украинской психиатрии. - Киев-Харьков, 2009. - Режим доступа : http://www.psychiatry.ua/articles/paper313.htm

9. Аддиктивный статус и ведущие стратегии совладения у пациентов с невротическими расстройствами и лиц общей популяции: сравнительный анализ / Н. А. Марута, С. П. Колядко, Г. Ю. Каленская, М. М. Денисенко // Психиатрия, психотерапия и клиническая психология. - 2016. - Т. 7, № 4. - С. 501-511. 


\section{References}

1. Hobbies, M.K., Voloshyn, P.V., Maruta, N.O., Zinchenko, O.M., Petrychenko, O.O. \& Diachenko, L.I. (2012). Stan psykhichnoho zdorovia naselennia ta perspektyvy rozvytku psykhiatrychnoi dopomohy $v$ Ukraini [The state of mental health of the population and the prospects for the development of psychiatric care in Ukraine]. Ukrainskyi visnyk psykhonevrolohiiUkrainian Journal of Psychoneurology, 20, 3 (72), 13-19 [in Ukrainian].

2. Voloshyn, P.V. \& Maruta, N.A. (2015). Strategiya okhrany psikhicheskogo zdorovya naseleniya Ukrainy: sovremennye vozmozhnosti i prepyatstviya [The strategy of mental health care of the population of Ukraine: contemporary opportunities and obstacles]. Ukrainskyi visnyk psykhonevrolohii - Ukrainian Journal of Psychoneurology, 23, 1 (82), 5-11 [in Russian]. 3. Chaban, O.S. (1997). Patomorfoz nevrozov (kliniko-psikhopatologicheskiye, sotsialno- psikhologicheskiye i konstitutsionalno-biologicheskiye zakonomernosti) [The pathomorphosis of neuroses (clinical-psychopathological, sociopsychological and constitutional-biological patterns)]. Extended abstract of Doctor's thesis. Kharkiv [in Russian].

4. Zilberblat, H.M. (2015). Reformuvannia psykhiatrychnoi sluzhby kriz pryzmu narkolohichnykh problem [The reforms of the mental health service through the prism of the substance abuse problems]. Ukrainskyi visnyk psykhonevrolohii Ukrainian Journal of Psychoneurology, 23, 3 (84), 74-78 [in Ukrainian].

5. Bitenskiy, V.S. (2006). Kliniko-psikhopatologicheskiye aspekty transformatsii addiktivnogo povedeniya $v$ usloviyakh «Informatsionnogo vzryva» [Clinical and psychopathological aspects of the transformation of addictive behavior in the conditions of the "Information explosion"]. Vísnyk psykhiatrii ta psykhofarmakoterapii - News of Psychiatry and Psychopharmacotherapy, 1, 161-167 [in Ukrainian].

6. Maruta, N.A., Kolyadko, S.P., Denisenko, M.M. \& Kalenskaya, G.Yu. (2015). Kliniko-psikhopatologicheskiye osobennosti trevozhno-fobicheskikh rasstroystv s addiktivnymi narusheniyami [Clinico-psychopathological features of anxiety-phobic disorders with addictive disorders]. Ukrainskyi visnyk psykhonevrolohii - Ukrainian Journal of Psychoneurology, 23, 2 (83), 115-116 [in Ukrainian].

7. Mendelevich, V.D. (2005). Psikhologiya deviantnogo povedeniya. Uchebnoye posobiye [Psychology of deviant behavior. Tutorial.]. Saint Petersburg: Rech [in Russian].

8. Linsky, I.V., Minko, A.I., Artemchuk, A.F., Grinevich, E.G., Markova, M.V. Musienko, G.A. et al. (2009). Sistema AUDITpodobnykh testov dlya kompleksnoy otsenki addiktivnogo statusa individa i populyatsii [A system of AUDIT-like tests for the complex estimation of the addictive status of an individual and a population]. Novosti ukrainskoy psikhiatrii - News of Ukrainian Psychiatry. Retrieved from: http://www.psychiatry.ua/articles/paper313.htm [in Russian].

9. Maruta, N.A., Kolyadko, S.P., Kalenskaya, G.Yu. \& Denisenko, M.M. (2016). Addiktivnyy status i vedushchiye strategii sovladeniya u patsiyentov $\mathrm{s}$ nevroticheskimi rasstroystvami i lits obshchey populyatsii: sravnitelnyy analiz [Addictive status and leading co-ownership strategies in patients with neurotic disorders and individuals in the general population: a comparative analysis]. Psikhiatriya, psikhoterapiya i klinicheskaya psikhologiya - Psychiatry, Psychotherapy and Clinical Psychology, 7(4), 501-511 [in Russian].

\section{ДИАГНОСТИЧЕСКИЕ КРИТЕРИИ НЕВРАСТЕНИИ С ПОВЫШЕННЫМ РИСКОМ АДДИКТИВНОГО ПОВЕДЕНИЯ \\ М.М. Денисенко \\ ГУ «Институт неврологии, психиатрии и наркологии НАМН Украины», г. Харьков, Украина}

Цель: определить клинические особенности и закономерности фрормирования неврастении с повышенным риском аддиктивного поведения.

Материалы и методы. В исследовании приняли участие 46 больных неврастенией (F 48.0), среди которых по данным AUDIT-подобных тестов оказалось 26 пациентов с аддикциями (основная группа) и 20 без аддикций (контрольная группа).

Результаты. По результатам проведенного исследования пациентов с неврастенией, совмещенной с аддиктивнными нарушениями, выявлено, что затяжной тип формирования невротического расстройства, наличие эмоционально-изоляционных психотравмирующих фракторов, широкий спектр клиникопсихопатологических симптомов с доминированием соматовегетативных и депрессивных проявлений, входящих в синдромальную структуру ведущего астенического синдрома на фроне соматовегетативного, дисфорического или депрессивного синдромов. Одним из самых информативных маркеров наличия аддикций у больных неврастенией является наличие затяжного начала болезни $(\mathrm{M} И=0,83)$ и диссрорического синдрома (МИ=0,8).

Причиной невротических расстройств с аддикциями было преимущественно сочетание острых и хронических психотравмирующих фракторов из разных сфрер жизнедеятельности человека; кроме этого значительная часть в формировании неврозов с аддикциями принадлежала эмоционально-изоляционным психотравмирующим фракторам, связанным с переживанием чувства одиночества и отчужденности.

Вывод. Полученные данные могут быть использованы для совершенствования программ диагностики, профилактики и терапии больных неврастенией.

КЛЮЧЕВЫЕ СЛОВА: неврастения, аддикция, коморбидность, клинико-психопатологические признаки, диагностические критерии. 
DIAGNOSTIC CRITERIA OF NEURASTHENIA WITH AN INCREASED RISK OF ADDICTIVE BEHAVIOR

M.M. Denysenko

Institute of Neurology, Psychiatry and Narcology of NAMS of Ukraine, Kharkiv

Purpose: to determine the clinical features and regularity of the formation of neurasthenia with increased risk of addictive behavior.

Materials and Methods. Clinical and psychopathological research; A system of AUDIT-like tests for comprehensive assessment of addictive status; A clinical questionnaire for the detection and evaluation of neurotic conditions.

Results. Thus, according to the results of the study of patients with neurasthenia associated with additive disorders, characterizes the protracted type of formation of a neurotic disorder, the presence of emotionallyisolating psycho traumatic factors, a wide range of clinical and psychopathological symptoms, with the dominance of somato-vegetative and depressive manifestations, as well as the representation in syndromic structure of the leading asthenic syndrome on the background of somato-vegetative, dysphoric or depressive syndromes. As the most informative markers for the presence of addictions in patients with neurasthenia, the presence of a protracted disease $(\mathrm{MI}=0.83)$ and dysphoric syndrome $(\mathrm{MI}=0.8)$ has been identified.

In the formation of neurotic disorders with addicts, the combination of acute and chronic psychotropic factors from various spheres of human life was used mainly; in addition, a significant part in the formation of neuroses with addictions belonged to the emotional and isolation psycho-traumatic factors associated with the experience of feeling of loneliness and alienation.

The obtained data can be used to improve the programs of diagnosis, prevention and therapy of patients with neurasthenia

KEY WORDS: neurasthenia; addictions; comorbidity; clinical-psychopathological signs; diagnostic criteria.

Рукопис надійшов до редакції 27.09.2017 p.

\section{Відомості про автора:}

Денисенко Михайло Михайлович - кандидат медичних наук, старший науковий співробітник відділу невідкладної психіатрії ДУ «Інститут неврології, психіатрії та наркології НАМН України»; тел. +38(050)-633-14-70. 